\title{
НАШЕ ТЕРМИНОЛОГИЈЕ И КУЛТУРА КЊИЖЕВНОГ ЈЕЗИКА
}

У данашње вријеме готово безнадно подијељеног свијета на развијени и неразвијени дио његов, у доба чистих и прљавих технологија, у доба које пријети пустошењем шумама и водама и у вријеме кад се наша земља налази на слабијој страни - сусрећемо се на нашем колегијалном састанку да подијелимо још једном традиционалну бригу: што да данас учинимо за наше терминологије. Бригу за „терминологију” у најширем смислу наша филологија је постојано узимала као бригу за језик и самим тиме као дио културе књижевног језика. То, наравно, подразумијева да се рад на терминологијама подвргава неким опћенито прихваћеним или, боље, подразумијевајућим постојаним засадама културе књижевног језика. Нпр.: а. Термин је дио књижевнога језика и рад на термину рад је на књижевном језику, б. Књижевни језик треба да буде „чист”, тј. рјечник књижевног језика треба и може да буде чист („Гдје имаш добру домаћу ријеч не узимај 'страну”, „'Стране' ријечи треба употребљавати умјерено"). У оквиру тога живи увјерење - морамо рећи наивно - да ће наше терминологизирање стићи на вријеме сваку технологију које се центар моћи налази изван овога језика и - у географском смислу - изван нас, па и изван континента којем и културно припадамо.

Осим тога, наша лингвистика (која је само у рецепцији отишла даље од традиционално и шире схваћене филологије) још дугује недвосмислене одговоре на два питања: 1. Признаје ли да термин може бити дио номенклатуре изван овога језика; и 2. Да ли је употреба нашега термина (који је изједначен с нашом ријечју) комуникацијски увјетована и вриједна - јер се „страна” ријеч или интернационални термин, како су неки стари терминолози наивно вјеровали (нпр. Ф. Кухач), не би разумјела - или је творба нашега термина, из наших морфема, сама по себи рад у корист чистоте књижевног језика, према томе сама по себи један облик патриотског рада. 
Мислим да је потребно уочити двије породице наших терминологија. Сасвим увјетно назват ћемо их отворене, које су отворене према народном благу, о њему овисе, као и о систему језика, у првом реду о правилностима творбе ријечи, и затворене, у необавезном односу према нашем језику, које се преузимају у дијеловима или у цјелини. Прве овисе о познавању богатога лексика и могућности наших грађења ријечи, других се тичу само опћи принципи стандардизације (фонолошко и акценатско прилагођавање), паранормативни поступци (транскрипције и транслитерације) или чак ни то. У прве ће се лако убројити ботаничка, фармаколошка и географска, у друге електроничка, нуклеарна и козмонаутичка.

Као опћи извори наших терминологија могу се означити: А. Језик оригиналнога говорника српскохрватског језика („народни језик”) као укупност могућности према стандардном штокавском, и Б. Преузимање и калковање страних или интернационалних термина и терминологија.

Народни језик мора се схватити као израван извор термина, постојећих ријечи које се узимају у терминологију. У поступку постојећа ријеч -> термин народни језик у изравном је односу с отвореним терминологијама. Тако народни језик може понекад и неочекивано снабдјети терминологије појмовима за које би се мислило да је потребно тражити нову ријеч. (Нпр. ријеч гағеви обнавља искуства сачувана у нашем језику с технолошким поступком који се примјењује данас у Индији, у доба енергетске кризе, В. Вук Караџић, Српски рјечник 1852.)

Проучавање језика и познавање народних ријечи, што значи познавање значења у језику као таквом, чак без посредства корпуса у рјечницима (који може и варати), има велико значење за отворене терминологије. Што је то познавање боље, терминологије ће бити поузданије. Нпр. наше знане рећи ће нам да је чичимак исто што и жижула, а чичвара исто што и сланутак. Ипак, у смислу методологије то је сакупљачки и записивачки рад, којим филологија и лексикографија множе своје увиде, али саме не биљеже напредак. Уједно је то и кушња за филологију: признати да у том оквиру постоји апсолутна синонимија на плану значења и експресије, к томе попустити или не попустити пориву ка паннормативизму, па увијек само једно проглашавати књижевним, а друго нечим другим или другоразредним. Овај други поступак био би у сваком случају противан нашим традиционалним поступцима и обичајима у књигама из природних наука, комуникацијски рестриктиван, културно затворен.

Ако се оно што зовемо култура језика уз претјерано повјерење лингвиста наметне дијелу рјечника који зовемо терминологијом, он ће наметнути неки свој опћенит принцип, па и када тај показује очите слабости суочен с реалним животом језика и конкретношћу језичног материјала. 
Ако је то принцип да се по сваку цијену избјегне интернационална ријеч (таква по функцији и распрострањености) прокажена као „страна”, онда такав принцип дјелује ограничавајуће на плану асоцијативности. „Биографија" ријечи, наше знање о томе из којега је језика, обично је олако схваћено као етимологија, и то таква да одмах утјече на положај ријечи у језику. (Ако бисмо се оградили од аустралске ријечи кенгур - у руху наших фонема - у корист ријечи клокан, умјесто да их видимо као синониме књижевнога језика, прикратили бисмо младога човјека у процесу образовања за асоцијацију на оно што учи на енглеском језику. Наравно, експресивна скала једне и друге ријечи питање је друге врсте.)

Противно овоме непродуктивном дјеловању, култура језика као захтјев за откривањем законитости језика продуктивно дјелује у затвореним терминологијама, као и у граничним случајевима.

Добро проучен и с поузданим осјећајем примијењен репертоар творбених морфема српскохрватског језика може растеретити: а. Модел који се дословно калкује, у првом реду њемачка сложеница, и б. творбене морфеме који се необазриво оптерећују, практички до разводњене каталогизације, као -ник.

Посебно проучавање (али не проучавање свакакве праксе, него стања у језику као таквоме, тј. народном језику) рећи ће нам како у математичкој и географској терминологији употријебити површина $\rightarrow$ nоврш, дужина $\rightarrow$ дуж, обоје ж. р. (Дуљина дужине или обратно дужина дуљине произвољно је и нефункционално, јер варијацијама ријечи приписује значење без ослонца у мотивацији или могућностима творбеног морфема.)

Однос наших терминологија и страних (занимљивих у првом реду колико су интернационалне) оцртава се као однос рецепције или мање или више успјелих замјена, а онда као проблем инвентивности у ширењу терминолошке базе од ријечи ка еуфонијској кратици, слици, фразему и могућностима језика у том смислу.

У рецепцији или у замјењивању уочавају се разни односи у фазама према језицима, у зависности од укупних односа (политичких, економских, културних и других), при чему се крилатица о узимању или неузимању „стране ријечи” провлачи с више или мање користи или штете. Разлика у глобалном односу јасна је: из њемачког изворишта ријечи се преводе дословно (свијетло - тамно пиво), без обзира на наше колоквијално стање (ирно - бијело), или према творбеном моделу (-ент у entkeimen даје откличити иако имамо нашу добру ријеч раскужити); напротив, из енглеског ријечи се преузимљу. Дакле, однос према терминима и терминологијама развија се од замјењивања или превођења до преузимања. Разлог за тако флуидан однос лежи међу осталим и у ин- 
тернационализацији у свијету као „глобалном селу” (Јапан осваја свијет помоћу енглескога језика), али и у томе што се не може повући оштра граница између термина и ријечи која то није. Или, боље речено између тога када језична јединица јест, а када није термин.

Чистој рецепцији лакше ће се дати ријечи и конструкције које не значе материјални појам, него апстрактан, начин вршења радње или став о њој, изграђен и убудуће држан изван наших критерија, на интернационалном плану.

Разлику у менталитету терминологизирања показује енглески интернационализиран термин у томе што између терминолога и „корисника" подразумијева заједничко знағе (код нас се подразумијева незнање - ријеч би се могла „не разумјети”, као што смо већ споменули), иде за практичношћу и опуштеношћу, што је страно нашем поступању, склоном дословном значењу саставних морфема. То су: 1 . Оказионално-анегдотско постање термина (hot $d o g)$, 2. еуфонијска кратица добивена краћењем у техници „змијског репа” (Hi-Fi), 3. рима која повезује двије радње (walkie-talkie), 4. практичност која подразумијева знање да је већ извршена једноставна математичка операција (калибар 357 заправо је $0,357), 5$. називи за родбинске односе са значењем производног дупликата или сродне привредне дјелатности (sistership).

Те моделске могућности изостају из наших терминологија (као модели који би се пунили из нашега језика), углавном што се ријеч као недјељива (и „инпенетрабилна”) јединица искључиво сматра термином.

Даљње изграђивање наших терминологија зависит ће и од пропусности стручних језика за колоквијалне јединице, стручне жаргоне, ономатопеје, способности градње према законитостима штокавскога језика, али и од повјерења терминолога у упућеност језичног колектива у стручна знања и знање интернационалних термина (које обично претходи покушају терминолога да нешто учини!). То значи да би наше терминологизирање измијенило своју физиономију кад би признало моћ схваћања и постојеће знање у друштву. То би извело наше новије терминологизирање из репродуктивности и неинвентивности, оптерећено слијепим преношењем опћих гесла̂ међународног договора, номенклатуре или нотације, поопћено речено и доведено до краја. Традиционалне отворене терминологије задржат ће нераскидиву везу с фондом народних ријечи, али тежња пантерминологизму намеће питање у односу на цијеле терминологије: има ли смисла преводити са терминологија које ће се у вртоглавом напретку (и первертирању) неких наука измијенити и застарјети прије него што се ишта значајније учини без реалне материјалне или производне основе (козмонаутика, микропроцесори). 
Терминологизирање једино у служби чистоте језика, схваћено као култура језика и патриотски гест по себи, ставља се у тежак положај да одржи корак с терминологизирањем које не гаји илузије о економској и културној самодовољности.

Устрајно истраживање структуре и супстанције нашега језика пружит ће још много користи у изградњи наших терминологија. Али умјереност у виђењу крајњег домета терминологизирања које би било интерпретирано као продужетак апстрактнијих идеала културе језика била би свакако добра страна настојања̂ на том плану у нашој свеколикој технолошкој зависности или - покушајмо се понадати - настојања која би помогла у нашем сналажењу у, рецимо утјешније, укупној међузависности данашњег свијета. 